\title{
Pertimbangan Hukum Hakim Terhadap Pengeroyokan Tukang Parkir oleh Pengemudi Ojek Online
}

\author{
Adiyatma Putra1, Made Warka1, Budiarsih' \\ ${ }_{1}^{1}$ Fakultas Hukum, Universitas 17 Agustus 1945 Surabaya \\ Email Correspondensi: adiyatmaputra1@gmail.com \\ No. Handphone Correspondensi : (+62) 82229091330
}

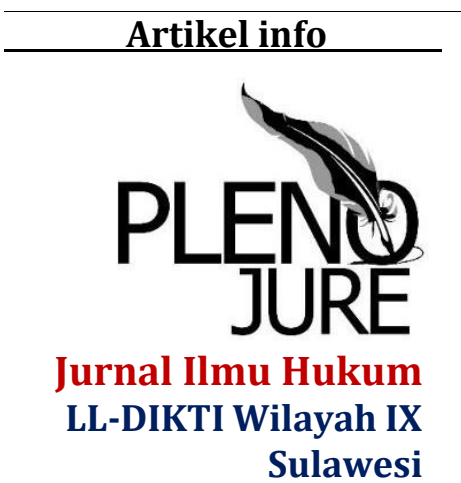

Artikel history:

Received; 09-07-2020

Revised:28-08-2020

Accepted;12-09-2020
Abstrak. Penelitian ini bertujuan untuk mengetahui regulasi kasus pidana kekerasan dalam Pidana Hukum di Indonesia dan menentukan pertimbangan hukum hakim dalam memutuskan nomor kasus 963/Pd/hon/PN.Mks. Ini penelitian adalah norma hukum, teknis, dan terapan penelitian. Penelitian ini juga menggunakan aturan hukum dan kasus pendekatan. Tipe data primer dan sekunder dulu memperoleh data penelitian. Hasilnya menemukan bahwa Regulasi kejahatan dengan kekerasan tercantum dalam Pidana Kode dan aturan hukum lainnya. Posisi Damai Surat dalam kasus kejahatan kekerasan sebagaimana diatur dalam pasal 170 ayat (2) KUHP dalam hal nomor 963/Pd/hon/PN.Mks bisa dikatakan sudah telah valid karena disepakati oleh kedua belah pihak. Namun, surat perdamaian seharusnya menulis persyaratan yang harus dipenuhi oleh terdakwa tersebut sebagai berikut: mengobati penyakit dan mengganti kehilangan barang dirusak oleh perilaku terdakwa. Dasar pertimbangan hakim dalam menjatuhkan sanksi terhadap kejahatan kekerasan sebagaimana diatur dalam pasal 170 ayat (2) KUHP dalam nomor kasus 963/Pid.B/ 2019 / PN.Mks. dalam hal ini, jaksa penuntut menggunakan dakwaan alternatif yaitu publik jaksa penuntut yang mendakwakan dakwaan itu, yaitu surat dakwaan Pasal 170 ayat (2) 1.

Abstract. This study aims to determine the regulation of criminal cases of violence in criminal law in Indonesia and determine the legal considerations of judges in deciding case number 963 / Pd / hon / PN.Mks. This research is a legal, technical, and applied research norm. This study also uses a rule of law and case approach. Primary and secondary data types first get research data. The results found that the Violent Crimes Regulation was contained in the Criminal Code and other legal regulations. The peaceful position of the letter in cases of violent crimes as stipulated in article 170 paragraph (2) of the Criminal Code in terms of number 963 / Pd / hon / PN.Mks can be said to have been valid because it was agreed by both parties.

However, the peace letter should write down the following requirements that the defendant must fulfil: treat illness and replace lost items damaged by the defendant's behaviour. The 
basis for the judge's consideration in imposing sanctions on violent crimes as stipulated in article 170 paragraph (2) of the Criminal Code in case number 963 / Pid.B / 2019 / PN.Mks. In this case, the prosecutor uses an alternative indictment, namely the public prosecutor who charges the indictment,

\author{
Keywords: \\ Pertimbangan \\ hukum; delik \\ pidana; kejahatan; \\ (5).
}

\section{PENDAHULUAN}

Indonesia adalah Negara Hukum, pernyataan itu terkandung dalam penjelasan UUD 1945 yang menyebutkan bahwa Negara Indonesia adalah negara yang berdasarkan hukum (rechtstaat). Sebagai negara hukum, Indonesia memiliki aturan dan peraturan yang ada sehingga kepentingan masyarakat dikatakan makmur jika tingkat ekonomi masyarakat dilindungi. Pembukaan UUD 1945 merupakan dasar telah menyebutkan bahwa salah satu tujuan negara adalah untuk menciptakan kesejahteraan masyarakat. Maka semua upaya dan pembangunan yang dilakukan oleh negara harus ditujukan untuk mewujudkan kesejahteraan rakyat.

Kehidupan manusia secara kodrati dapat dikualifikasikan sebagai makhluk sosial (zoon politicon) dalam memenuhi kebutuhan hidupnya, sehingga antara satu dengan yang lain saling membutuhkan. Di lain pihak kebutuhan dan kepentingan manusia tersebut terdapat banyak perbedaan. Perbedaan tersebut dapat dipastikan akan berpotensi terjadinya perselisihan serta konflik yang pada akhirnya sangat mungkin akan timbul permasalahan hukum termasuk perkara pidana, sehingga diperlukan suatu norma yang mengatur kehidupan manusia dalam bersosial. Norma adalah aturan, patokan, atau ukuran, yaitu sesuatu yang sifatnya fixed atau 'mapan' yang terhadapnya hal-hal lain diperbandingkan atau dipertanyakan. ${ }^{1}$ Hans Kelsen ${ }^{2}$ menyebutkan bahwa an impersonal and anonymous 'command' - that is the norm (norma ialah perintah yang tidak personal dan anonim).

Dalam ilmu hukum, norma (normwissenschaf) merupakan bagian dari ilmu hukum yang membahas tentang perumusan norma hukum, apa yang dimaksud norma hukum abstrak dan konkrit, isi dan sifat norma hukum, esensialia norma hukum, tugas dan kegunaan norma hukum, pernyataan atau tanda pernyataan norma hukum, penyimpangan terhadap norma hukum, dan

\footnotetext{
${ }^{1}$ Sumaryono, E. (1995). Etika profesi hukum: Norma-norma bagi penegak hukum. Kanisius. Jakarta. hal, 55

2 Indrati, M. F. (2013). Ilmu Perundang-undangan Jilid 2 (Proses dan Teknik pembentukannya). Kanisius, Jakarta. hal, 201
} 
keberlakuan norma hukum. ${ }^{3}$ Dalam sistem hukum di Indonesia, norma hukum ini disebut juga sebagai norma hukup positif yang memiliki sifat kepastian hukum, yaitu norma yang terkandung dalam Undang-undang Dasar 1945, peraturan perundang-undangan (wetgeving), dan bahkan dalam peraturan kebijakan (beleidsregels). ${ }^{4}$ Penyimpangan norma merupakan bentuk pelanggaran dalam ketentuan hukum yang berlaku. Hal ini dapat menyebabkan berbagai kejahatan di masyarakat dalam bentuk tindak pidana kejahatan, pencurian, pemukulan, perampokan dan sebagainya, dapat menyebabkan terganggunya keamanan di masyarakat. Ini bertentangan dengan Pasal 28G ayat (1) dan (2) UUD 1945 yang menyatakan bahwa: "(1) Setiap orang berhak atas perlindungan diri pribadi, keluarga, kehormatan, martabat, dan harta benda yang di bawah kekuasaannya, serta berhak atas rasa aman dan perlindungan dari ancaman ketakutan untuk berbuat atau tidak berbuat sesuatu yang merupakan hak asasi; (2) Setiap orang berhak untuk bebas dari penyiksaan atau perlakuan yang merendahkan derajat martabat manusia dan berhak memperoleh suaka politik dari negara lain."

Salah satu bentuk kejahatan yang paling sering muncul pada saat itu adalah pemukulan. Aksi pemukulan adalah fenomena yang sulit dihilangkan dalam kehidupan sosial, krena lebih mudah dilakukan saat terjadi bentrok antara orang yang satu dengan yang lain. Beberapa jenis pemukulan yang sering terjadi seperti pemukulan dan kekerasan fisik yang dilakukan bersama terhadap orang lain sering mengakibatkan cedera pada anggota tubuh korban, tidak jarang membuat korban cacat fisik seumur hidup bahkan sampai mati.

Salah satu kasus pemukulan yang dilakukan bersama-sama terjadi di Makassar di mana kasus telah sampai pada pemutusan perkara oleh Hakim di Pengadilan Negeri Makassar yaitu telah dikeluarkannya putusan perkara nomor 963/Pid.B/2019/PN.Mks. Permasalahan yang ingin diangkat dalam penelitian ini adalah bahwa sebelum putusan perkara tersebut dikeluarkan, maka terlebih dahulu sudah dikeluarkan surat perdamaian di luar pengadilan dan telah disepakati oleh kedua belah pihak, terlihat bahwa isu hukum ini menjadi sebuah kajian penting diera pemanfaatan teknologi informasi diberbagai sektor kehidupan dewasa ini. ${ }^{5}$

Berdasarkan uraian di atas, peneliti termotivasi untuk menganalisis studi hukum lebih lanjut mengenai tindak pidana kekerasan yang dilakukan bersama, sehingga penulis memilih judul "Pengeroyokan Tukang Parkir oleh Pengemudi Grab Online (Studi Putusan Pengadilan Negeri Makassar)“, dengan permasalahan utama sebagai berikut: Bagaimana keputusan hakim dalam mengatasi perkara tindak pidana kekerasan sebagaimana diatur dalam pasal

\footnotetext{
${ }^{3}$ Darmodiharjo, D., \& Shidarta, P. P. F. H. (2006). Apa dan Bagaimana Filsafat Hukum Indonesia, Jakarta: PT. Gramedia Pustaka Utama. hal, 19

4 ibid. hal, 250

${ }^{5}$ Qamar, N., \& Aswari, A. (2018). Healing or Hurting: Development of Highway Public

Transportation Technology. Jurnal Dinamika Hukum, 18(3), 319-328. hal, 320
} 
170 ayat (2) ke-1 KUHP pada perkara nomor 963/Pid.B/2019/PN.Mks?.

\section{METODE}

Penelitian ini menggunakan pendekatan yuridis normatif. Pendekatan ini memungkinkan studi ini untuk menggambarkan dan mendiskusikan konsepkonsep politik dan prinsip-prinsip hukum, ${ }^{6}$ di mana akan digunakan untuk menjelaskan aspek-aspek hukum dalam norma-norma hukum yang ada. Selain itu, juga dapat mendukung studi dalam mengidentifikasi dan memverifikasi temuan bahan non-hukum untuk memenuhi persyaratan penelitian hukum. ${ }^{7}$ Penelitian ini juga menggunakan pendekatan hukum dan pendekatan kasus. Tipe data primer dan sekunder digunakan untuk memperoleh data penelitian.

\section{HASIL DAN PEMBAHASAN}

Sarjana hukum Indonesia membedakan istilah hukuman dan pidana yang dalam Bahasa Belanda hanya dikenal dengan satu istilah umum untuk keduanya, merupakan straf. Istilah hukuman adalah istilah umum untuk segala macam sanksi baik perdata, administratif, disiplin dan pidana. Sedangkan istilah pidana diartikan sempit yang berkaitan dengan hukum pidana. ${ }^{8}$ Muladi dan Barda Nawawi Arief, ${ }^{9}$ menyimpulkan bahwa pidana mengandung unsurunsur atau ciri-ciri yaitu: 1) Pidana itu pada hakikatnya merupakan suatu pengenaan penderitaan atau nestapa atau akibat-akibat lain yang tidak menyenangkan. 2) Pidana itu diberikan dengan sengaja oleh orang atau badan yang mempunyai kekuasaan (oleh yang berwenang), 3) Pidana itu dikenakan kepada seseorang yang telah melakukan tindak pidana menurut undangundang.

Pemidanaan bisa diartikan sebagai tahap penetapan sanksi dan juga tahap pemberian sanksi dalam hukum pidana. Kata "pidana" pada umumnya diartikan sebagai hukum, sedangkan "pemidanaan" diartikan sebagai penghukuman. Pemidanaan sebagai suatu tindakan terhadap seorang penjahat, dapat dibenarkan secara normal bukan trutama karena pemidanaan itu mengandung konsekuensi-konsekuensi positif bagi si terpidana, korban, dan juga masyarakat. Karena itu teori ini disebut juga teori konsekuensialisme. Ada berbagai macam pendapat mengenai teori pemidanaan ini, namun yang banyak itu dapat dikelompokkan kedalam tiga golongan besar, yaitu 1) Teori absolut atau teori pembalasan (vergeldings theorien), 2) Teori Relative atau Teori Tujuan, 3) Teori Gabungan.

\footnotetext{
${ }^{6}$ Ali, Z. (2013). Metode Penelitian Hukum (cetakan keempat). Jakarta. Sinar Grafika. HIm, 24

7 ibid., hal, 105

${ }^{8}$ Hamzah, A., \& Rahayu, S. (1983). Suatu Tinjauan Ringkas Sistem Pemidanaan di Indonesia. Akademika Pressindo. hal, 20.

${ }^{9}$ Ekaputra, M., \& Kahir, A. (2010). Sistem Pidana Di Dalam KUHP Dan Pengaturannya Menurut Konsep KUHP Baru. Medan, USUpress. hal, 2
} 


\section{Tindak Pidana}

Pidana disebut sebagai criminal dalam terminologi Bahasa Inggris, yang berarti bersifat kejahatan. Kejahatan atau crime didefinisikan sebagai "acts, or failure to act, that a society has decided it wants to punish".10,11 Artinya, tindak pidana merupakan tindakan atau kegagalan tindakan, di mana masyarakat telah memutuskan untuk memberi hukuman kepada tindakan tersebut. Dengan kata lain, tindak pidana adalah tindakan yang layak untuk mendapatkan hukuman dari masyarakat. Dalam konteks hukum,12 dinyatakan bahwa kejahatan adalah "an intentional act or failure to act that is in violation of criminal law, committed without defense or excuse, and penalized by the state as a felony ${ }^{13}$ or misdemeanor." ${ }^{14}$ Artinya bahwa kriminal adalah tindakan yang disengaja atau kegagalan untuk bertindak yang di dalamnya terdapat penyelewengan terhadap hukum pidana, yang dilakukan dengan tanpa pertahanan atau dalih, serta diputuskan secara hukum untuk mendapatkan sanksi, baik berupa hukuman penjara maupun denda materi.

Pengertian tindak pidana dalam Kitab Undang-Undang Hukum Pidana dikenal dengan istilah strafbaar feit dan dalam kepustakaan tentang hukum pidana sering mempergunakan istilah delik, sedangkan pembuat undangundang merumuskan suatu undang-undang mempergunakan istilah peristiwa pidana atau perbuatan pidana atau tindak pidana. Tindak pidana merupakan suatu istilah yang mengandung suatu pengertian dasar dalam ilmu hukum sebagai istilah yang dibentuk dengan kesadaran dalam memberikan ciri tertentu pada peristiwa hukum pidana. Tindak pidana mempunyai pengertian yang tidak dapat dilihat dari peristiwa-peristiwa yang pada kenyataannya berada dalam ranah hukum pidana, sehingga tindak pidana haruslah diberikan arti yang bersifat ilmiah dan ditentukan dengan jelas untuk dapat memisahkan dengan istilah yang dipakai sehari-hari dalam kehidupan masyarakat. ${ }^{15}$

Tindak pidana dapat dibedakan atas dasar-dasar tertentu, yakni: 1). Menurut sistem KUHP, 2). Menurut cara merumuskannya, 3)Berdasarkan bentuk kesalahan, 4) Berdasarkan Macam Perbuatannya, 5) Berdasarkan saat dan jangka waktu terjadinya, 6) Berdasarkan sumbernya, 7) Dilihat dari sudut

\footnotetext{
${ }^{10}$ Petras, H., Kellam, S. G., Brown, C. H., Muthén, B. O., Ialongo, N. S., \& Poduska, J. M. (2008). Developmental epidemiological courses leading to antisocial personality disorder and violent and criminal behavior: Effects by young adulthood of a universal preventive intervention in firstand second-grade classrooms. Drug and alcohol dependence, 95, S45-S59.

${ }^{11}$ Elaine Cassel dan Douglas A. Bernstein, Criminal Behavior, Second Edition, Lawrence Erlbaum Associates, Inc., New Jersey, 2007, hal,2.

12 ibid., hal, 12

${ }^{13}$ Felony adalah kejahatan yang bisa dihukum dan dimasukkan ke lembaga pemasyarakatan atau lembaga lain, seperti lembaga rehabilitasi, untuk periode satu tahun kehidupan. Capital felony merupakan kejahatan yang memiliki potensi untuk dihukum mati.

${ }^{14}$ Misdemeanor merupakan kejahatan yang bisa dihukum dengan penahanan selama setahun atau kurang di penjara lokal dan diharuskan membayar denda.

15 Kartonegoro, Diktat Kuliah Hukum Pidana, Balai Lektur Mahasiswa, Jakarta, 2002, hal. 62.
} 
pandangnnya, 8) Berdasarkan perlu tidaknya pengaduan dalam hal penuntutan, 9) Berdasarkan berat-ringannya pidana yang diancamkan, 10) Berdasarkan kepentingan hukum yang dilindungi, 11) Dari sudut berapa kali perbuatan untuk menjadi suatu larangan.

Ada dua unsur tindak pidana yaitu unsur objektif dan unsur subjektif. Unsur obejektif antara lain perbuatan orang, akibat yang kelihatan dari perbuatan tersebut, mungkin ada keadaan tertentu yang menyertai perbuatan. Sedangkan unsur subjektif orang yang mampu bertanggung jawab, adanya kesalahan. Perbuatan harus dilakukan dengan kesalahan, kesalahan ini dapat berhubungan dengan akibat dari perbuatan atau dengan keadaan mana perbuatan itu dilakukan.

Untuk lebih jelasnya, Simons ${ }^{16}$ menyebutkan adanya unsur objektif dan unsur subjektif dari tindak pidana (strafbaar feit). Unsur objektif antara lain perbuatan orang, akibat yang kelihatan dari perbuatan itu, mungkin ada keadaan tertentu yang menyertai perbuatan tersebut seperti dalam Pasal 281 KUHP sifat openbaar atau "di muka umum". Sedangkan Unsur subjektif: orang yang mampu bertanggung jawab, adanya kesalahan (dollus atau culpa). Perbuatan harus dilakukan dengan kesalahan, kesalahan ini dapat berhubungan dengan akibat dari perbuatan atau dengan keadaan mana perbuatan itu dilakukan.

Hukum pidana Indonesia mengenal 2 (dua) jenis pidana yang diatur dalam Pasal 10 KUHP antara lain:

1. Pidana pokok:
a. Pidana mati.
b. Pidana penjara.
c. Pidana kurungan.
d. Pidana denda.
e. Pidana tutupan.

2. Pidana tambahan:
a. Pencabutan hak-hak tertentu.
b. Perampasan barang-barang tertentu.
c. Pengumuman putusan hakim.

\section{Tindak Pidana yang Dilakukan Bersama-sama (Pengeroyokan)}

Dalam kasus atau perkara perbuatan pidana yang dilakukan secara bersama-sama baik dengan massa yang terbentuk secara terorganisir dan massa yang terbentuk tidak secara terorganisir, memiliki pola dan maksud yang lebih berkelompok. Pola dan maksud memiliki makna yang berbeda, "Pola" hanya menjelaskan tentang latar belakang perbuatan yang dilakukan

${ }^{16}$ Hamzah, A., \& Pidana, A. A. H. (2010). Jakarta, Rineka Cipta. hal, 8 
seseorang. Maka karakter menjawab pertanyaan mengapa pelaku berbuat, sedangkan "maksud" bermakna menjelaskan tentang apa yang akan dicapai terhadap pelaku dengan perbuatannya, maka lebih menerangkan pada tujuan tertentu dari suatu perbuatan.

Mengacu pada fakta-fakta kejahatan, kekerasan khususnya dalam hal tersebut perbuatan pidana yang dilakukan secara massal cukup banyak menguatkan perbedaan dalam pola dan maksudnya. ${ }^{17}$ Selain ini, perbuatan pidana bersama-sama ini juga melahirkan bentuk-bentuk tindakan/perbuatan yang berbentuk dan berkelompok sehingga lebih sulit untuk menentukan kuasa kejahatan. ${ }^{18}$ Travis Hirschi ${ }^{19}$ menjelaskan bahwa terdapat 4 bahan ikatan sosial (social bond) dalam setiap masyarakat, di mana hal ini dapat menjadi penyebab terjadinya tindak pidana bersama-sama atau pengeroyokan, yaitu:20

a. Attachment adalah kemampuan manusia untuk melibatkan dirinya terhadap orang lain, dan apabila attachment tersebut telah berbentuk, maka orang tersebut akan mudah terhadap pikiran, perasaan, dan akan orang lain. Attachment diartikan secara bebas dengan keterikatan, ikatan pertama yaitu keterikatan dengan orang tua, keterikatan dengan sekolah (guru) dan dengan teman seangkatan.

b. Commitment adalah keterikatan seseorang pada bagian-bagian sistem berdasarkan seperti sekolah, pekerjaan,organisasi dan sebagainya. Karena dengan perjanjian atau keterikatan akan mendapatkan manfaat bagi orang tersebut dikarenakan kegiatan yang diikutinya. Manfaat tersebut dapat berupa harta benda, perbuatan, masa depan dan sebagainya.

c. Invoiverment adalah kegiatan seseorang dalam bagian-bagian sistem. Maka seseorang berperan aktif dalam organisasi maka kecil keinginan untuk melakukan penyimpangan. Logika gambaran tersebut adalah apabila orang aktif disegala kegiatan maka mereka akan menghabiskan waktu dan tenaganya dalam kegiatan tersebut.

d. Belief adalah tanda moral yang terdapat dalam ikatan sosial, dan tentunya berbeda dengan ketiga tanda di atas. Belief merupakan kepercayaan seseorang pada nilai-nilai moral yang ada. Kepercayaan seseorang terhadap norma-norma yang ada menimbulkan kepatuhan terhadap seseorang terhadap normanorma yang ada menimbulkan kepatuhan terhadap norma tersebut.

\footnotetext{
17 Martono, M. (2020). Perlindungan Hukum Terhadap Penangkapan dan Penahanan Tersangka dalam Perspektif Hak Azasi Manusia. Al-Ishlah: Jurnal Ilmiah Hukum, 22(1), 98-114. hal, 103

${ }^{18}$ Atmasasmita, R. (1992). Teori dan kapita selekta Kriminologi. Bandung, Eresco. hal, 31

19 Zulfa, E. A., \& Santoso, T. (2001). Kriminologi. Asas-Asas Hukum Pidana dan Kriminologi serta Perkembangannya Dewasa ini, Universitas Gajah Mada, Yogyakarta, 23-27.

${ }^{20}$ Hanifah, R. A., \& Dengan Hukum, A. F. A. B. Faktor Determinan Remaja Pelaku Pencurian: Perspektif Teori Kontrol Sosial. Psikologi Klinis Dalam Konteks Pemasyarakatan.
} 


\section{Penjelasan Visum Et Repertum}

Penjelasan Visum Et Repertum berasal dari kata visual, misalnya melihat dan repertum yaitu melaporkan, maksudnya: "yang dilihat dan apa yang ditemukan, sehingga Visum Et Repertum merupakan suatu laporan tertulis dari dokter (ahli) yang dibuat berdasarkan sumpah, perihal apa yang dilihat dan ditemukan terhadap bukti hidup, mayat atau fisik ataupun barang bukti lain, kemudian dilakukan pemeriksaan berdasarkan pengetahuan yang sebaikbaiknya. berdasarkan tersebut selanjutnya diambil kesimpulan, yang juga merupakan pendapat dari seorang ahli ataupun kesaksian (ahli) secara tertulis sebagaimana yang tertulis dan tertuang dalam bagian "pemberitaan" (hasil pemeriksaan). ${ }^{21}$

\section{Kekuatan Hukum Perjanjian Perdamaian yang Dilakukan Pihak Bersengketa di Luar Pengadilan}

Pelaksanaan perjanjian perdamaian salah satu pihak wanprestasi, maka pihak yang merasa dirugikan dapat menuntut pemenuhan perjanjian, dan/atau pembatalan perjanjian disertai atau tanpa disertai ganti biaya, rugi dan bunga kelalaian kepada pengadilan. Apabila perjanjian perdamaian didaftarkan di Pengadilan Negeri menurut ketentuan Pasal 6 ayat (7) Undang-undang Nomor 30 Tahun 1999, tentang Arbitrase dan Alternatif Penyelesaian Sengketa, dan ternyata salah satu pihak wanprestasi, maka pihak yang merasa dirugikan dapat mengajukan gugatan ke Pengadilan Negeri dengan permintaan putusan serta merta dilaksanakan walaupun tergugat banding atau kasasi (Uitvoerbaar bij voorraad), demikian Pasal 180 HIR atau Pasal 191 RBg dapat dijadikan dasar.

Pengertian perjanjian perdamaian adalah suatu perjanjian dengan mana kedua belah pihak, dengan menyerahkan, menjanjikan atau menahan suatu barang, mengakhiri suatu perkara yang sedang bergantung atau mencegah timbulnya suatu perkara. Dalam praktiknya suatu perjanjian perdamaian adalah merupakan suatu akta, karena perjanjian tersebut sengaja dibuat oleh pihak-pihak yang bersangkutan untuk dijadikan alat bukti dengan tujuan untuk menyelesaiakan sengketa. Sedangkan Menurut Subekti,22 perdamaian merupakan perjanjian formal, karena diadakan menurut suatu formalitas tertentu, bila tidak maka perdamaian tidak mengikat dan tidak sah.

Perjanjian tersebut tidak sah, melainkan jika dibuat secara tertulis. Agar perjanjian perdamaian dinilai sah menurut hukum, harus memenuhi syarat-

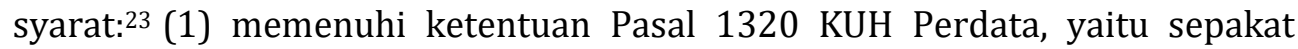
mereka yang mengikatkan dirinya, kecakapan untuk membuat suatu perikatan, suatu hal tertentu, dan suatu sebab yang halal; dan (2) Pasal 1851 ayat 2 KUH Perdata, menentukan perjanjian perdamaian dibuat secara tertulis. Mengenai hal ini menurut Wirjono Prodjodikoro, dibuat dengan tulisan (schriftelijk) tidak

21 Setiady, T. (2009). Pokok-pokok Ilmu Kedokteran Kehakiman. Bandung: Alfabeta. hal, 39-40

22 Subekti, A. P. (2001). Hukum Perjanjian, cetakan 19. Jakarta: Intermasa. hal, 178

23 ibid, hal, 189 
selalu berupa akta, melainkan dianggap cukup apabila ada surat menyurat antara kedua belah pihak, yang cocok satu sama lain (Hoge Road Belanda tanggal 30-6-1949 N.J.1950,137).

Terkait dengan kasus pengeroyokan sebagaimana tertera pada putusan perkara nomor 963/Pd/hon/PN.Mks maka sebelum putusan tersebut ditetapkan oleh Pengadilan Negeri Makassar, sudah ada surat perjanjian perdamaian di antara dua pihak yang bersengketa. Dalam surat perjanjian perdamaian tersebut kedua para pihak saling melepaskan sebagian tuntutan mereka, demi untuk mengakhiri suatu perkara yang sedang bergantung atau untuk mencegah timbulnya suatu perkara. Penyelesaian melalui surat perdamaian yaitu: 1) Pihak pertama dan pihak kedua telah sama menyadari bahwa pertikaian antara pihak pengemudi ojek online Grab dan pihak juru parkir dibawah terowongan Mall Panakukang diakibatkan kesalahpahaman/khilafan masing-masing pihak. 2) Pihak pertama dan pihak kedua telah bersepakatan mengakhiri pertikaian dan menyelesaikan secara kekeluargaan. 3) Sehubungan dengan telah selesaianya secara kekeluargaan pihak pertama tidak akan menuntut pihak kedua begitu pula sebaliknya dan akan mencabut laporan polisi tersebut. 4) Apabila kedua belah pihak tidak menepati kesepakatan kami tersebut diatas, maka kami kedua belah pihak bersedia dituntut menurut hukum yang berlaku.

\section{Pertimbangan Hakim dalam Menjatuhkan Putusan}

Pertimbangan hakim atau Ratio Decidendi adalah argumen atau alasan yang dipakai oleh hakim sebagai pertimbangan hukum yang menjadi dasar sebelum memutus perkara. Dalam praktik sebelum pertimbangan yuridis ini dibuktikan, maka hakim terlebih dahulu akan menarik fakta-fakta dalam persidangan yang timbul dan merupakan konklusi komulatif dari keterangan para saksi, keterangan terdakwa, dan barang bukti.

Fakta-fakta persidangan yang dihadirkan, berorientasi dari lokasi, waktu kejadian, dan modus operandi tentang bagaimana tindak pidana itu dilakukan. Selain itu, dapat pula diperhatikan bagaimana akibat langsung atau tidak langsung dari perbuatan terdakwa, barang bukti apa saja yang digunakan, serta apakah terdakwa dapat mempertanggungjawabkan perbuatannya atau tidak.

Apabila fakta-fakta dalam persidangan telah diungkapkan, barulah hakim mempertimbangkan unsur-unsur delik yang didakwakan oleh penuntut umum. Pertimbangan yuridis dari delik yang didakwakan juga harus menguasai aspek teoritik, pandangan doktrin, yurisprudensi, dan posisi kasus yang ditangani, barulah kemudian secara limitative ditetapkan pendiriannya Setelah pencantuman unsur-unsur tersebut, dalam praktek putusan hakim, selanjutnya dipertimbangkan hal-hal yang dapat meringankan atau memperberatkan terdakwa. Hal-hal yang memberatkan misalnya terdakwa sudah pernah dipidana sebelumnya (Recidivis), karena jabatannya, dan menggunakan 
bendera kebangsaan. Hal-hal yang bersifat meringankan ialah terdakwa belum dewasa, perihal percobaan dan pembantuan kejahatan.

Undang-Undang No. 48 Tahun 2009 Pasal 5 ayat (1) yang menyatakan bahwa hakim wajib menggali, mengikuti, dan memahami nilai-nilai hukum dan rasa keadilan yang hidup dalam masyarakat. ketentuan ini dimaksudkan agar putusan hakim sesuai dengan hukum dan rasa keadilan masyarakat. Jadi, hakim merupakan perumus dan penggali nilai-nilai hukum yang hidup di kalangan rakyat. Oleh karenanya, ia harus terjun ke tengah-tengah masyarakat untuk mengenal, merasakan dan mampu menyelami perasaan hukum dan rasa keadilan yang hidup dalam masyarakat.

Adapun bunyi Pasal 170 ayat (2) ke-1 KUHP adalah sebagai berikut: Barang siapa dengan terang-terangan dan secara bersama-sama menggunakan kekerasan terhadap orang atau barang, diancam dengan pidana penjara paling lama lima tahun enam bulan. Jika melihat Pasal ini maka jelas Pasal ini mengatur tentang tindak pidana, yaitu kekerasan terhadap orang atau barang, yang mengakibatkan luka atau kerusakan.

Dasar Pertimbangan Hakim untuk menjatuhkan putusan terhadap pelaku tindak pidana kekerasan yang dilakukan secara bersama-sama terhadap orang di muka umum maka hakim membuat pertimbangan-pertimbangan. Menurut analisis penulis, Hakim dalam menjatuhkan putusan pidana terhadap pelaku tindak pidana kekerasan yang diakukan secara bersama-sama terhadap orang dimuka umum menggunakan pertimbangan yang bersifat yuridis dan nonyuridis. Pertimbangan yang bersifat yuridis adalah pertimbangan hakim yang didasarkan pada fakta-fakta yang terungkap didalam persidangan atau faktorfaktor yang terungkap didalam persidangan dan oleh Undang-Undang telah ditetapkan sebagai hal yang harus dimuat didalam putusan.

Terhadap perkara Nomor 963/Pd/hon/PN.Mks, Majelis Hakim sebelum menjatuhkan putusan melakukan pertimbangan-pertimbangan baik itu dari aspek yuridis maupun pertimbangan dari aspek psikologis dan sosiologis. Pertimbangan-pertimbangan yuridis terhadap tindak pidana yang didakwakan merupakan konteks yang paling penting dalam putusan Hakim dan merupakan unsur-unsur dari suatu delik apakah perbuatan terdakwa tersebut telah memenuhi dan sesuai dengan rumusan delik yang didakwakan oleh Jaksa Penuntut Umum. Pertimbangan-pertimbangan yuridis ini secara langsung akan berpengaruh besar terhadap amar putusan Majelis Hakim.

Berdasarkan pertimbangan-pertimbangan Majelis Hakim tersebut kemudian diperoleh fakta-fakta untuk selanjutnya dimusyawarahkan oleh Majelis Hakim dalam mengambil putusan. Selama pemeriksaan dipersidangan pada diri terdakwa tidak ditemukan alasan penghapus pertanggungjawaban pidana dan alasan pembenar bagi terdakwa dalam melakukan tindak pidana sehingga dengan demikian terdakwa adalah subjek hukum yang mampu bertanggungjawab atas perbuatannya dan oleh karenanya harus dinyatakan bersalah atas perbuatanya tersebut. 


\section{SIMPULAN DAN SARAN}

Berdasarkan jabaran pembahasan yang telah diuriakan, kesimpulan penelitian ini dijabarkan sebagai berikut: (1) Kedudukan Surat Perdamaian dalam perkara tindak pidana kekerasan sebagaimana diatur dalam pasal 170 ayat (2) ke-1 KUHP pada perkara nomor 963/Pid.B/2019/PN. Surat perdamaian memiliki kekuatan hukum yang sama halnya dengan keputusan hakim yang berkekuatan hukum. Dengan demikian, dapat diketahui bahwa akta perdamaian yang dibuat tersebut memiliki kekuatan hukum yang tetap, sehingga tidak dapat diganggu gugat; dan (2) Dasar Pertimbangan Hakim dalam penjatuhan sanksi terhadap tindak pidana kekerasan sebagaimana diatur dalam pasal 170 ayat (2) ke- 1 KUHP pada perkara nomor 963/Pid.B/2019/PN.Mks adalah Dasar Pertimbangan Hakim untuk menjatuhkan putusan terhadap pelaku tindak pidana kekerasan yang dilakukan secara bersama-sama terhadap orang di muka umum maka hakim membuat pertimbangan-pertimbangan.

Berdasarkan jabaran kesimpulan yang telah diuriakan, saran pada penelitian ini adalah: (1) Pidana yang dijatuhkan oleh Hakim bukan saja ditujukan bagi diri si pelaku tindak pidana, tetapi juga ditujukan dan diharapkan berdampak pada masyarakat pada umumnya, maka dalam menjatuhkan pidana. Majelis Hakim diharapkan memperhatikan tujuan pemidanaan, sehingga masyarakat akan menyadari dan tahu bahwa melakukan tindak pidana akan dikenakan sanksi sesuai dengan peraturan perundang-undangan yang ada; dan (2) Surat Perdamaian seharusnya lebih ditekankan lagi sehingga tidak merugikan pihak pertama dan pihak kedua, dan majelis hakim juga hendaknya memberikan edukasi terhadap masyarakat tentang surat perdamaian sehingga masyarakat bisa mengunakan surat tersebut dengan sebaik-baiknya.

\section{DAFTAR RUJUKAN}

Ali, Z. (2013). Metode Penelitian Hukum (cetakan keempat). Jakarta. Sinar Grafika.

Atmasasmita, R. (1992). Teori dan kapita selekta Kriminologi. Bandung, Eresco.

Darmodiharjo, D., \& Shidarta, P. P. F. H. (2006). Apa dan Bagaimana Filsafat Hukum Indonesia, Jakarta: PT. Gramedia Pustaka Utama.

Elaine Cassel dan Douglas A. Bernstein, (2007). Criminal Behavior, Second Edition, Lawrence Erlbaum Associates, Inc., New Jersey.

Hamzah, A., \& Rahayu, S. (1983). Suatu Tinjauan Ringkas Sistem Pemidanaan di Indonesia. Akademika Pressindo. 
Ekaputra, M., \& Kahir, A. (2010). Sistem Pidana Di Dalam KUHP Dan Pengaturannya Menurut Konsep KUHP Baru. Medan, USUpress.

Hanifah, R. A., \& Dengan Hukum, A. F. A. B. Faktor Determinan Remaja Pelaku Pencurian: Perspektif Teori Kontrol Sosial. Psikologi Klinis Dalam Konteks Pemasyarakatan.

Hamzah, A., \& Pidana, A. A. H. (2010). Jakarta, Rineka Cipta.

Indrati, M. F. (2013). Ilmu Perundang-undangan Jilid 2 (Proses dan Teknik pembentukannya). Kanisius, Jakarta.

Kartonegoro, Diktat Kuliah Hukum Pidana, Balai Lektur Mahasiswa, Jakarta, 2002

Martono, M. (2020). Perlindungan Hukum Terhadap Penangkapan dan Penahanan Tersangka dalam Perspektif Hak Azasi Manusia. Al-Ishlah: Jurnal Ilmiah Hukum, 22(1), 98-114.

Petras, H., Kellam, S. G., Brown, C. H., Muthén, B. O., Ialongo, N. S., \& Poduska, J. M. (2008). Developmental epidemiological courses leading to antisocial personality disorder and violent and criminal behavior: Effects by young adulthood of a universal preventive intervention in first-and second-grade classrooms. Drug and alcohol dependence, 95, S45-S59.

Qamar, N., \& Aswari, A. (2018). Healing or Hurting: Development of Highway Public Transportation Technology. Jurnal Dinamika Hukum, 18(3), 319-328.

Setiady, T. (2009). Pokok-pokok Ilmu Kedokteran Kehakiman. Bandung: Alfabeta. hal, 39-40

Subekti, A. P. (2001). Hukum Perjanjian, cetakan 19. Jakarta: Intermasa.

Sumaryono, E. (1995). Etika profesi hukum: Norma-norma bagi penegak hukum. Kanisius. Jakarta.

Zulfa, E. A., \& Santoso, T. (2001). Kriminologi. Asas-Asas Hukum Pidana dan Kriminologi serta Perkembangannya Dewasa ini, Universitas Gajah Mada, Yogyakarta, 23-27. 